\title{
PRINSIP-PRINSIP HERMENUTIKA \\ GENRE EPISTOLARI PAULUS: SUATU PEDOMAN EKSEGESIS \\ Jani $^{*}$ \\ jannilewi@gmail.com \\ Sekolah Tinggi Teologi Injili Indonesia, Yogyakarta
}

\begin{abstract}
The books in the Bible have their own characteristics that are categorized into genres. The uniqueness of each genre demands a hermeneutic inquiry appropriate to its genre. Therefore this paper aims only to present the principles of the hermeneutics of Paul's epistolary genre as a guide to the exegesis of the New Testament. The principles presented consist of several elements, namely: text translation; Investigate the context; Categorize the types of rhetoric of texts; Semantic study, grammatical investigation, and investigate the use of the Old Testament in the New Testament.
\end{abstract}

Key Words: Principles, Genre, Epistolary, Hermeneutic, Exegesis

\section{Pendahuluan}

Salah satu hal terpenting untuk membantu agar pemaknaan terhadap teks Alkitab akurat adalah kesetiaan terhadap prinsip-prinsip hermeneutika yang bertanggung jawab. Tanpa sikap dan kesadaran ini, seseorang akan bertindak serampangan dan bukan tidak mungkin kajiannya justru menyimpang jauh dari makna yang sesungguhnya. Untuk mengantisipasi bahaya tersebut, maka tuntunan prinsip-prinsip hermeneutika adalah urgen demi memfasilitasi upaya tersingkapnya kebenaran. Untuk kepentingan itu, artikel ini akan menyuguhkan prinsip-prinsip hermeneutika genre epistolari Paulus. Unsur-unsur yang disajikan di sini belum mencakup semua prinsip secara keseluruhan. Karena keterbatasan ruang, hanya beberapa prinsip saja yang dikemukakan secara terbatas.

\section{Pentingnya Penafsiran Berdasarkan Genre Literatur Kitab}

Belakangan ini para sarjana telah menyadari betul bahwa barangkali isu yang lebih penting dari penafsiran adalah isu mengenai genre. ${ }^{1}$ Karenanya jika seorang penafsir salah memahami genre sebuah teks, maka analisisnya layak dipertanyakan. Misalnya, bisa saja seseorang menafsirkan dongeng sebagai laporan sejarah dengan cukup mendalam, tetapi interpretasi tersebut cacat fatal dari awal karena salah membaca genre teks. Jadi, salah satu hal yang sangat penting dalam mengkaji Alkitab dengan benar adalah memahami bagian-bagian Alkitab berdasarkan jenis-jenis genrenya. Karena jenis genre kitab yang terdapat dalam Alkitab sangat beragam, maka prinsip pendekatan hermeneutik terhadap genre tersebut pun haruslah selaras dengan genrenya. Dengan kata lain, setiap jenis bentuk sastra memiliki kaidah-kaidah dasar, strategi, dan tujuannya yang khas. E. D. Hirsch Jr menyamakan hal ini dengan game;

\footnotetext{
*JANI, M.TH., D.TH (STTII Yogyakarta), adalah dosen spesialisasi Perjanjian Baru di Sekolah Tinggi Teologi Injili Indonesia, Yogyakarta.

${ }^{1}$ Istilah "genre" di sini merujuk pada kategori atau jenis tulisan yang ditandai oleh bentuk-bentuk atau isi tertentu.
} 
untuk memahami hal itu dengan benar kita perlu mengetahui permainan apa yang sedang dimainkan. Kita juga perlu mengatahui peraturan permainan. ${ }^{2}$

\section{Memahami Format Surat dalam Dunia Kuno}

Hal surat-menyurat sudah dikenal cukup luas di dunia kuno. Di kala itu, format surat nampaknya memiliki format yang sudah agak dibakukan, khususnya surat yang bersifat resmi atau formal. Karena hidup di zaman Greko-Roman, Paulus kelihatannya menulis surat-surat kirimannya menurut kaidah-kaidah umum yang sudah dikenal luas di kala itu. Pertimbangan ini penting agar jemaat sebagai pembaca mula-mula menyadari sifat dan isi beritanya yang mendesak dan serius.

\section{Format Surat di Dunia Greko-Roman}

Menurut Klein, Blomberg dan Hubbard, untuk menafsirkan genre epistel Perjanjian Baru secara tepat, kita perlu memperbandingkannnya dengan surat-surat zaman purbakala lainnya dari dunia Greko-Roman. ${ }^{3}$ Rupanya di dunia kuno, berita-berita hanya dikirim melalui kurir-kurir. Pada periode tersebut, perputaran informasi penuh keterbatasan. Namun menjelang abad ketiga SM, berita-berita kemudian dikirim via kepingan-kepingan kayu atau tanah liat, atau lembaran-lembaran papirus. Menurut beberapa pakar, di Timur Dekat Kuno, sudah banyak konvensi epistolari beredar (seperti kalimat pembuka dan ucapan syukur) yang diduga berasal dari periode lisan dan juga tulisan melalui kepingan-kepingan. ${ }^{4}$ Menurut White, pada periode ini kebanyakan jenis surat bersifat resmi yang melaporkan tentang masalah-masalah militer dan sipil yang ditujukan kepada raja atau pejabat lainnya. ${ }^{5}$

Umumnya semua format surat yang beredar di periode kuno tersebut terdiri dari tiga bagian utama: bagian pembuka, batang tubuh (isi), dan penutup surat. Menurut David Aune, pembuka dan penutup surat mengikuti pola-pola konvensional, sedangkan batang tubuh sangat berbeda, bergantung pada pokok masalah yang tidak diklasifikasikan dengan mudah. Bagian isi dan gaya dari surat tersebut bisa berbeda-beda tergantung pada status hubungan antar pengirim dan penerima. ${ }^{6}$

\section{Unsur-unsur Formal Surat Kiriman Paulus}

Terkait dengan format surat-surat Paulus, para pakar kontemporer telah melakukan berbagai penelitian yang cermat guna mengetahui hubungan antara surat-surat Paulus dan

\footnotetext{
${ }^{2}$ E. D. Hirsch Jr, Validity in Interpretation (New Haven: Yale University Press, 1967), 70.

${ }^{3}$ William W. Klein, Craig L. Blomberg, Robert L. Hubbard Jr., Introduction to Biblical Interpretation, jil. 2 pen., Timotius Lo, peny., Chilianha Jusuf (Malang: Literatur SAAT, 2013), 390.

${ }^{4}$ Dennis Pardee, "An Overview of Ancient Hebrew Epistolography," JBL 97, no. 3:321-46; John L. White, "The Ancient Epistolography Group in Retrospect," Semeia 22:1-14; Joseph A. Fitzmyer, “Aramaic Epistolograph," Semeia 22:25-26.

${ }^{5}$ John L. White, “Ancient Greek Letter," dalam Greco-Roman Literature and the New Testament: Selected Forms and Genre, peny., D. E. Aune (Atlanta: Scholars Press, 1988), 85-86.

${ }^{6}$ David Aune, The New Testament in Its Literary Environment (Philadelphia: Westminster Press, 1987), 158-59. Dalam epistel-epistel Yunani, bagian salam seringkali singkat: “___ kepada ___ salam dan sejahtera." Bagian penutup juga mengenakan suatu formula dengan šâlôm. Ada dua tipe, "Saya mengirim surat ini agar damai ada dalam pikiranmu" dan "damai sejahtera." Fitzmyer, "Aramaic Epistolograph," 36.
} 
tulisan surat-surat kuno di dunia Yunani-Romawi seperti yang dijelaskan di atas. ${ }^{7}$ Salah satu pakar yang karyanya banyak dipublikasikan terkait dengan studi ini adalah Adolf Deissmann. ${ }^{8}$ Dulu, setelah mengamati praktik-praktik epistolari Helenistik dan Yahudi, Deissmann meyakini bahwa epistel-epistel Paulus merupakan surat-surat pribadi ketimbang epistel-epistel sastra, ${ }^{9}$ tetapi sekarang pandangan tersebut telah banyak dibantah. ${ }^{10}$

Unsur-unsur surat Paulus memiliki kesamaan dengan surat-surat kuno dalam bentuk standar (tanggal, salam, tubuh surat, penutup, dan tanda tangan). Ribuan surat kuno telah ditemukan dan kebanyakan dari surat-surat tersebut mempunyai bentuk yang tepat sama dengan surat-surat yang ada di Perjanjian Baru (band. Surat dari Majelis di Yerusalem di Kis. 15:2329). ${ }^{11}$ Dalam penelitiannya terhadap unsur-unsur formal yang terdapat dalam surat-surat Paulus, C. J. Roetzel melihat kemiripan yang sangat dekat dengan format surat dalam dunia GrekoRoman. Yakni, dimulai dengan sebuah salam pembukaan (identifikasi dari sang penulis, para penerima, dan sejenis ucapan salam) dan sebuah doa atau pernyataan ucapan syukur atas keadaan baik dari para penerima surat. Selanjutnya, penulis akan melanjutkan ke dalam isi surat tersebut, yang mencantumkan alasan-alasan utama penulisan surat tersebut. Jika sang penulis memiliki nasihat atau dorongan semangat untuk disampaikan, maka itu disampaikan setelah isi surat. Sebuah ucapan perpisahan penutup mengakhiri dokumen ini. ${ }^{12}$

Jika menyelidiki bentuk surat-surat Paulus, paling tidak ada enam unsur formal yang mencirikan tulisan-tulisannya, yakni:

1. Nama penulis (mis. "Paulus")

2. Nama penerima (mis. "kepada jemaat Allah di Korintus")

3. Salam pembukaan (mis. "kasih karunia dan damai sejahtera dari Allah, Bapa kita ...")

4. Doa harapan dan ucapan syukur (mis. "Aku senantiasa mengucap syukur kepada Allah karena kamu...")

5. Batang tubuh

6. Salam penutup (mis. "Kasih karunia Tuhan Yesus menyertai kamu”)

Satu-satunya unsur yang tak tetap dalam bentuk ini ialah nomor empat, yang dalam kebanyakan surat kuno mengambil bentuk doa dan harapan atau dihilangkan sama sekali (seperti dalam Kitab Galatia, 1 Timotius, dan Titus), walaupun kadang-kadang seorang menemukan suatu ucapan syukur dan doa (sebagaimana sering terdapat dalam surat-surat Paulus). Dalam tiga Surat Kiriman Perjanjian Baru ucapan syukur ini berubah menjadi suatu kidung pujian (2 Korintus; Efesus; 1 Petrus; band. Wahyu 1:5-6). Tampaknya surat-surat kiriman Perjanjian Baru yang tidak memiliki unsur-unsur formal 1-3 atau 6 tidak termasuk surat-surat yang benar, walaupun bentuknya sebagian bersifat surat kiriman.

Jadi, pemahaman akan unsur-unsur seperti itu akan memampukan para penafsir memahami apa yang bersifat tipikal atau atipikal yang terdapat dalam surat-surat kiriman Perjanjian Baru. Doa dan ucapan syukur pembuka, yang pasti bersifat lebih teologis

${ }^{7}$ Lihat, Richard N. Longenecker, "On the Form, Function, and Authority of the New Testament Letters," dalam Scripture and Truth, peny. D. A. Carson dan John D. Woodbridge (Grand Rapids: Zondervan, 1983), 102-14 . John L. White, "Ancient Greek Letter," dalam Greco-Roman Literature and the New Testament: Selected Forms and Genre, peny., D. E. Aune (Atlanta: Scholars Press, 1988), 85-86. Joseph A. Fitzmyer, "Aramaic Epistolograph," Semeia 22:25-26.

${ }^{8}$ Adolf Deissmann, Light from the Ancient East, pen., L. R. M. Strachan (London: Hodder \& Stoughton, 1909).

${ }^{9}$ Ibid., 224-46. Dalam keyakinannya hanya surat-surat umum saja yang merupakan epistel-epistel sastra. D. Dormeyer, The New Testament Among the Writings of Antiquity, pen., R. Kossov (Sheffield: Sheffield Academic Press, 1998), 23

${ }^{10}$ Lihat Grant R. Osborne, The Hermeneutic Spiral: A Comprehensive Introduction to Bible Interpretation (Downer Grove, Ill.: InterVarsity Press, 1991), 254-56

${ }^{11}$ Douglas Stuart dan Gordon D. Fee, How to Read the Bible for All Its Worth (Grand Rapids: Zondervan, 1993), 50-51.

${ }^{12}$ C. J. Roetzel, The Letter of Paul (Louisville: Westminster John Knox, 1998), 51-66. 
dibandingkan dengan rata-rata surat "sekuler" lainnya, sebenarnya menampilkan sebuah tata krama yang bersifat umum yang menjadi perhatian semua penulis.

\section{Prinsip-prinsip Hermeneutika Genre Epistolari Paulus}

Dalam menganalisis genre epistolari Paulus, hanya beberapa prinsip hermeneutika saja yang akan dikaji sebagai metode dasar, yakni; terjemahan teks; menyelidiki konteks; mengkategorikan jenis retorika teks; melakukan studi semantik, menyelidiki gramatikal, menyelidiki penggunaan Perjanjian Lama dalam Perjanjian Baru.

\section{Menterjemahkan Teks}

Sebelum seorang penafsir lebih jauh melangkah ke dalam penelitian terhadap teks, langkah pertama yang tidak boleh dilewatkan adalah menterjemahkan teks yang dianalisis terlebih dahulu. Hal ini sangat penting karena surat-surat Paulus ditulis dalam bahasa Yunani, maka itu berarti bagi seorang penafsir alat utama untuk membaca serta mempelajari tulisantulisan tersebut adalah menterjemahkannya. Karena adanya kesenjangan bahasa kita dengan pembaca awal, mengharuskan penterjemahan teks Yunani ke bahasa Indonesia akhirnya bersifat wajib. Urgensi ini juga ditegaskan Fee, karena menterjemahkan teks adalah cara utama yang paling penting jika penafsir ingin menjadi akrab dengan paragraf yang diteliti. ${ }^{13}$ Lebih lanjut ia menegaskan pentingnya langkah ini karena "Tidak ada yang dapat menolong kita dalam melakukan ini lebih baik selain membaca paragraf kita sendiri dalam bahasa Yunani dan membuat sebuah terjemahan sementara." ${ }^{4}$ Itu berarti tugas penafsiran bukan menjadi satusatunya garapan para akademisi saja, melainkan setiap orang yang ingin menambang mutiara kebenaran dari Alkitab.

Bagi penafsir awal tuntutan untuk melakukan tugas ini di rasa sesuatu yang sangat berat. Daripada terhalang lama di sana, ia memilih untuk melompat langsung kepada menafsirkan teks-teks tersebut. Tindakan ini umumnya terjadi karena dua hal: pengetahuan yang masih terbatas terhadap bahasa Yunani dan minimnya tools relevan yang dimiliki untuk melakukan langkah pertama ini. Jadi untuk memperoleh pertolongan dalam melakukan langkah awal ini, ada beberapa saran yang perlu diperhatikan. Pertama, mempelajari terjemahan Alkitab yang baik dalam bahasa Inggris dan bahasa Indonesia. Ini bukan hal yang buruk; hal ini memang tak terelakkan. Akan tetapi apa yang dimaksud adalah bahwa dalam suatu arti tertentu orang yang membaca Alkitab hanya dalam bahasa Inggris atau bahasa Indonesia berada di dalam kekuasaan para penerjemah, dan para penerjemah sering harus melakukan pilihan tentang apa sebenarnya yang dimaksudkan oleh teks Yunani asli. Untuk tugas ini, penafsir bisa membandingkan terjemahan antara NKJV, NASB, TNIV, NEB, NET. Manakah terjemahan yang harus digunakan? Dalam hal ini masing-masing orang harus menentukan pilihannya sendiri. ${ }^{15}$

Kedua, membuat terjemahan sendiri. Bagi mereka yang memiliki pengetahuan bahasa Yunani, seharusnya bisa mengikuti proses ini tanpa banyak kesulitan. Untuk melakukan tugas ini penafsir disarankan untuk menggunakan alat bantu kamus, interlinear, dan program komputer seperti bibleworks9. Bila mengalami kesulitan dengan beberapa konsep tata bahasa

\footnotetext{
${ }^{13}$ Gordon D. Fee, New Testament Exegesis, pen., dan peny., Andreas Hauw (Malang: Literatur SAAT, 2011), 13.

${ }^{15}$ Untuk membuat pilihan yang bijaksana, penafsir perlu mengetahui beberapa hal, baik tentang ilmu penerjemahan itu sendiri, maupun tentang beberapa di antara berbagai terjemahan dalam bahasa Inggris. Untuk memperoleh diskusi yang mendalam tentang dua hal ini, lihat Stuart dan Fee, How to Read the Bible for All Its Worth, khususnya halaman 33-48, disertai contoh-contoh yang sangat bermanfaat.
} 
(sintaksis), disarankan menggunakan alat bantu yang sudah tersedia dalam bahasa Indonesia, seperti; interlinear Yunani-Indonesia karya Hasan Sutanto, Perjanjian Baru Interlinear YunaniIndonesia dan Konkordansi, jilid 1 dan 2 (Jakarta: Lembaga Alkitab Indonesia, 2002) dan B. F. Drewes, Wilfrid Haubeck, dan Heinrich von Siebenthal, Kunci Bahasa Yunani Perjanjian Baru: Surat Roma Hingga Kitab Wahyu, peny., Chrisostomus Sihotang (Jakarta: BPK Gunung Mulia, 2011). Untuk bahasa Inggris gunakan karya J. D. Douglas (editor), The New Greek-English Interlinear New Testament (Wheaton, Ill.: Tyndale House Publishers, 1990).

Bagaimana memulai terjemahan? Untuk memperoleh teknik mendasar dari mana kita harus memulai menterjemahkan teks Yunani, disarankan untuk membaca dan mengikuti saran penting yang ditunjukkan oleh Gordon D. Fee, New Testament Exegesis, pen., dan peny., Andreas Hauw (Malang: Literatur SAAT, 2011), khususnya halaman 53-72, disertai dengan contoh-contoh.

\section{Menyelidiki Konteks}

Tidak dapat dipungkiri lagi bahwa penyelidikan konteks merupakan salah satu prinsip dasar dari hermeneutika biblika yang bertanggung jawab. Menurut Klein, Blomberg, Hubbard penyelidikan konteks terasa sangat penting karena tiga alasan utama; Pertama konteks menyediakan alur pikiran; kedua konteks menyediakan makna akurat dari kata-kata; dan terakhir konteks melukiskan hubungan-hubungan yang benar antar unit. ${ }^{16}$ Pada bagian ini penyelidikan konteks difokuskan pada konteks historis-kultural dan konteks logis.

\section{Konteks Historis-Kultural yang Melatarbelakangi Teks}

Menurut Fee, hal pertama yang harus dilakukan dengan setiap surat kiriman Paulus adalah membentuk suatu rekonstruksi yang sementara namun arif dari situasi yang sedang dihadapi oleh penulis. ${ }^{17}$ Prinsip ini kemudian menjadi sangat penting karena makna satu teks rupanya tidak dapat ditafsirkan dengan satu tingkat kepastian tanpa analisis historis-kultural. ${ }^{18}$ Hal senada ditegaskan Klein, Blomberg, Hubbard dengan mengatakan "Inilah dasar bagi seluruh prinsip hermeneutika yang penting: Penafsiran yang benar atas teks Alkitab akan konsisten dengan latar belakang historis-budaya dari teks tersebut. ${ }^{\text {19 }}$ Kesimpulan ini berarti bahwa setiap bagian Alkitab pada mulanya dituliskan bagi pembaca tertentu yang hidup di tempat dan waktu tertentu, dan mempunyai tujuan tertentu. Dan ketidaktahuan tentang kebiasaan budaya tertentu mungkin menyebabkan kesalahan interpretasi. Itu sebabnya, Roy B. Zuck dengan tepat menyimpulkan bahwa mengabaikan konteks historis adalah salah satu masalah terbesar dalam penafsiran Alkitab. ${ }^{20}$

Penyelidikan historis dan kultural yang dimaksudkan di sini berbeda dengan studi kritik sejarah (historical criticism) dalam hal menerapkan data latar belakang kepada suatu perikop untuk lebih memahami maknanya, namun tidak digunakan untuk menentukan otensitas atau penambahan editorial yang dilakukan terhadap teks itu. Tugas dari kritik sejarah adalah menyingkapkan data dan fakta secara arkeologis. Tujuan utamanya lebih kepada tujuan-tujuan apologetik untuk "membuktikan" otensitas dari kisah Alkitab. Memang ada kegunaan tertentu

\footnotetext{
${ }^{16}$ Klein, Blomberg, Hubbard, Introduction to Biblical Interpretation 2, 7-12.

${ }^{17}$ Stuart dan Fee, How to Read the Bible for All Its Worth, 53.

${ }^{18}$ Henry A. Virkler \& Karelynne Gerber Ayayo, Hermeneutik: Prinsip-prinsip dan Proses Interpretasi Alkitabiah (Yogyakarta: ANDI, 2015), 77.

${ }^{19}$ Klein, Blomberg, Hubbard Jr., Introduction to Biblical Interpretation 2, 33.

${ }^{20}$ Roy B. Zuck, Basic Bible Interpretation (Wheaton, Ill.: Victor Books, 1991), 77.
} 
dalam menggunakan arkeologi untuk menegaskan kebenaran tulisan Alkitab, ${ }^{21}$ seperti kontribusinya dalam menyediakan informasi sosiologis kepada pembaca modern agar dapat lebih memahami lingkungan di mana suatu perikop atau peristiwa Alkitab ditulis. Akan tetapi, relevansinya bagi hermeneutika masih diperdebatkan. Menurut Osborne, sering kali masalah yang ditimbulkan dari penemuan-penemuan arkeologi lebih besar dari solusi yang diberikan. ${ }^{22}$

Konteks "historis" yang dimaksudkan di sini adalah latar di mana kitab-kitab di dalam ditulis dan keadaan-keadaan yang terkait dengan penulisan. Atau lebih kepada aspek diakronis, berkaitan dengan lingkungan di mana Paulus menghasilkan karya-karyanya. Sedangkan konteks "kultural" yang dipahami di sini lebih kepada aspek sinkronis, merujuk kepada cara, kebiasaan, aturan dan prinsip yang mewarnai suatu masa tertentu dan membentuk lingkungan di mana orang-orang menjalani kehidupan mereka. Jika menggunakan pengertian yang dipakai oleh Roy B. Zuck, konteks ini merujuk kepada keseluruhan pola perilaku manusia yang mencakup pemikiran, pembicaraan, tindakan, dan artefak (benda, barang-barang hasil kecerdasan manusia seperti perkakas, senjata, dsb.) dan sebagai kepercayaan umum bentuk-bentuk sosial, dan sifatsifat material dari suatu kelompok ras, agama, atau sosial. Dengan demikian konteks kultural mencakup apa yang dipikirkan dan dipercayai oleh orang-orang, apa yang dikatakan, dilakukan, dan dibuat oleh mereka. Ini mencakup kepercayaan mereka, politik, hukum, arsitektur, bisnis, ekonomi, geografi di mana orang tersebut hidup dan melakukan perjalanan, bentuk-bentuk komunikasinya, kebiasaan dan praktik-praktik, serta benda-benda material seperti alat-alat, tempat tinggal, senjata, dan seterusnya. ${ }^{23}$

Jadi, ketika membaca surat-surat Paulus, penting seorang penafsir mengetahui apa yang dipikirkan, dipercayai, dikatakan, dilakukan, dan dibuat oleh orang-orang yang menerima dan membaca suratnya. Jika penafsir melakukan hal ini, maka ia akan dapat memahaminya dengan lebih baik dan mengkomunikasikannya dengan lebih akurat. Secara konklusif Alan Johnson mengatakan bahwa "Kepedulian terhadap konteks mendorong kita menjauh dari pengertian pribadi dan kembali kepada . . . kerangka kerja penulisnya." ${ }^{24}$ Dan bagi Bernard Ramm, perhatian terhadap studi ini memungkinkan kita mengetahui makna asli, harfiah, dan makna sosial dari suatu kebiasaan, kata atau frasa tersebut, tanpa bantuan studi tersebut interpretasi harfiah akan lumpuh. ${ }^{25}$

Dalam melakukan analisi konteks historis-kultural, ada dua prinsip yang menuntun seorang penafsir agar dapat secara tepat menangani berbagai latar belakang historis-budaya dari tulisan Paulus.

\section{Latar Belakang Historis Penulis dan Penerima}

Sebelum menyelidiki kalimat, paragraf, atau bagian kecil manapun dari sebuah dokumen, seorang penafsir selalu perlu memiliki pengertian yang baik akan seluruh dokumen tersebut. Hal ini mencakup berbagai fakta yang terkait dengan siapa penulisnya, penerima, tanggal dan tujuan kitab tersebut. Tidak ada cara pengganti apa pun untuk langkah ini. Penafsir harus menangkap gambaran besar keseluruhan kitab tersebut. Saat melakukan analisis Stuart dan Fee menyarankan empat unsur yang penting diselidiki.

\footnotetext{
${ }^{21}$ Contoh klasik adalah dari W. M. Ramsay, St. Paul the Traveller and Roman Citizen (Grand Rapids: Baker, 1949), seorang sejarawan besar dan agnostik yang melakukan studi mengenai bukti-bukti arkeologis di balik Injil Lukas dan Kisah Para Rasul, dia bertobat karena hasil studinya ini.

${ }^{22}$ Osborne, Hermeneutical Spiral, 128.

${ }^{23}$ Zuck, Basic Bible Interpretation, 79.

${ }^{24}$ Alan Johnson, "History and Culture in New Testament Interpretation," dalam Interpreting the Word of God, peny., Samuel J. Schultz dan Morris A. Inch (Chicago: Moody Press, 1976), 131.

${ }^{25}$ Bernard Ramm, Protestant Biblical Interpretation (Grand Rapids: Baker Book House, 1970), 157.
} 
1. Carilah segala hal tentang para penerima. Apakah mereka orang Yahudi atau non Yahudi? Atau mereka adalah campuran? Apa hubungan mereka dengan penulis?

2. Selidiki sikap-sikap Paulus. Apakah sikap Paulus terhadap semua ini berubah-ubah di antara teguran, imbauan, dan nasihat?

3. Carilah segala hal tentang tujuan penulis. Apakah penulis secara terang-terangan mengatakan hal itu? Apakah tujuan itu hanya tersirat? Menurut Walter C. Kaiser Jr, seperti yang dikutip oleh Virkler dan Ayayo, ada tiga cara dasar untuk melakukan hal ini. Pertama, perhatikan pernyataan eksplisit penulis atau pengulangan frasa tertentu. Kedua, amati bagian paraenetik (dorongan) dari tulisan ini. Ketiga, amati selektivitas penulis, maksudnya, poin-poin yang dihilangkan. ${ }^{26}$

4. Amatilah pembagian yang wajar dan logis dari surat ini. Apakah ada petunjuk-petunjuk untuk pembagian pasal-pasal? Apakah ada pokok-pokok pembicaraan yang sudah berbeda dari pasal sebelum dan sesudahnya? Untuk mengerjakan hal ini mulailah dengan pembagian-pembagian utama yang nyata. ${ }^{27}$

Pengetahuan awal mengenai informasi butir pertama di atas dapat ditemukan dalam sumber-sumber seperti survei dan pengenalan singkat Alkitab, buku tafsiran, kamus Alkitab, atau ensiklopedia. Beberapa sumber yang sangat bermanfaat dalam melakukan analisis ini antara lain: D. A. Carson, D. J. Moo, dan L. Morris, An Introduction to the New Testament (Grand Rapids: Zondervan, 1992); Donald Guthrie, New Testament Introduction (Downers Grove: InterVarsity, 1990). Buku ini merupakan pembahasan yang paling komprehensif dari kubu konservatif tentang isu-isu pengantar. R. Gundry, A Survey of the New Testament (Grand Rapids: Zondervan, 1994). Buku pengantar yang ringkas, namun merupakan survei terbaik untuk tingkatan mendasar.

\section{Latar Belakang Kultural}

Agar sebuah hasil penafsiran memenuhi syarat dan dapat diterima sebagai makna yang dimaksudkan dari sebuah teks, menurut Klein, Blomberg, Hubbard, ia harus merupakan makna yang paling sesuai dengan keadaan-keadaan asli dari penulisan dan pembacaan teks tersebut. Penjelasan apa pun yang tidak sesuai dengan situasi dan kondisi historikal atau kultural dari penulis dan para penerimanya tidak dapat diterima sebagai tafsiran yang absah. ${ }^{28}$ Lebih lanjut dikatakan bahwa dengan mempertimbangkan keadaan-keadaan asli di sekitar penulisan teks, seorang penafsir harus menentukan tafsiran mana yang mengandung makna yang paling alamiah? Prinsip ini menyiratkan bahwa seorang penafsir harus memahami situasi historikal dan kultural seakurat mungkin dan harus menafsirkan Alkitab secara konsisten dengan gambaran tersebut. ${ }^{29}$

Karena surat-surat Paulus adalah dokumen yang bersifat peristiwa-peristiwa dan itu berbeda-beda dari kitab ke kitab (yakni, surat-surat itu dihasilkan karena beberapa keadaan khusus, entah dari sudut pandang para pembacanya atau penulis sendiri), jadi adalah penting untuk merekonstruksi situasi para penerima surat, seperti; situasi sosial-ekonomi mereka, situasi politik, situasi kota, sumber kehidupan utamanya, geografi, budaya-budaya yang dipraktikkan dan lain sebagainya. Karena kebanyakan dokumen Perjanjian Baru ditujukan kepada komunitas gereja dalam dunia Yunani-Romawi, maka seorang penafsir paling tidak memiliki pengetahuan mengenai unsur-unsur di atas.

\footnotetext{
${ }^{26}$ Virkler \& Ayayo, Hermeneutik, 82-83.

${ }^{27}$ Dalam melakukan analsisi ini, Stuart dan Fee mengangkat contoh dari 1 Korintus secara khusus, sehingga langkah-langkah hermeneutik yang mereka sarankan menjadi konkrit dan mudah dimengerti para penafsir pemula. How to Read the Bible for All Its Worth, 53-59.

${ }^{28}$ Klein, Blomberg, Hubbard Jr., Introduction to Biblical Interpretation 2, 39.

${ }^{29}$ Ibid.
} 
Meskipun para ekseget modern menghadapi berbagai rintangan saat melakukan kajian ini ${ }^{30}$ namun ada berbagai sumber yang merupakan jalan masuk ke dalam "dunia" Perjanjian Baru, khususnya surat-surat Paulus. Untuk pandangan mengenai politik, agama, dan cara berpikir pada masa abad pertama Yudaisme dan Roma Helenis, penafsir perlu akses pada satu atau dua sumber berikut, yakni: Everett Ferguson, Background of Early Christianity (Grand Rapids: Wm. B. Eerdmand Publishing Co., 1993); Craig A. Evans dan Stanley E. Porter (editor), Dictionary of New Testament Background (Downer Grove, Ill.: InterVarsity Press, 2000); James S. Jeffers, The Background of Early Christianity (Downer Grove, Ill.: InterVarsity Press, 1999); Craig Keener, The IVP Bible Background Commentary: New Testament (Downer Grove, Ill.: InterVarsity Press, 1993) buku pengantar mengenai persoalan-persoalan yang berakibat pada teks-teks untuk seluruh kitab Perjanjian Baru.

Untuk latar belakang Yunani-Romawi secara khusus, ada satu sumber yang sangat menolong: Helmut Koester, Introduction to the New Testament, jil. 1: History, Culture, and Religion of the Hellenistic Age (Minneapolis: Fortress Press, 1995). Untuk latar belakang sosiologis dan budaya lihat Carolyn Osiek, What Are They Saying about the Social Setting of the New Testament? (New York: Paulist Press, 1992) dan Carolyn Osiek dan David L. Balch, Families in the New Testament World: Household and House Churches (Louisville: Westminster John Knox, 1997).

\section{Konteks Logis}

Konteks historis-kultural memang penting dilakukan, tetapi konteks tersebut bukan satusatunya penentu. Tanpa mempertimbangkan konteks logis dari teks, penafsir dimungkinkan kehilangan arah dari yang semestinya. Bahkan menurut Osborne konteks logis harus dimengerti sebagai faktor yang paling mendasar dalam penafsiran, karena konteks logis sendiri memiliki serangkaian pengaruh-pengaruh yang luas atas suatu teks. ${ }^{31}$ Dalam usulan Osborne terkait dengan konteks logis, seorang penafsir harus mendekati sebuah teks dengan menggunakan pendekatan yang ia sebut "belajar Alkitab secara induktif" yaitu membuat bagan keseluruhan suatu kitab dan membuat diagram dari paragraf-paragrafnya. Dengan demikian penyelidikan dimulai dari lingkaran luar terlebih dahulu (mempelajari keseluruhan: membuat bagan suatu kitab), baru kemudian lingkaran dalam (mempelajari bagian-bagian: membuat diagram dari paragraf). Pendekatan ini kebalikan dengan yang diusulkan Klein, Blomberg, Hubbard. ${ }^{32}$

\section{Membuat Bagan Suatu Kitab}

Perlu ditekankan sekali lagi bahwa semua bagian teks tidak memiliki makna jika terlepas dari konteks keseluruhannya. Hanya dengan memperhatikan pesan dari keseluruhan perikoplah seorang penafsir akhirnya dapat mempelajari bagian-bagian berikut untuk memperoleh detaildetail pesan intinya. Dalam praktiknya, Osborne mengusulkan proses hermeneutika yang dilakukan dapat dirangkum dengan cara berikut:

1. Buatlah bagan keseluruhan dari suatu kitab untuk menganalisa alur pikiran yang ada dalam kitab.

\footnotetext{
${ }^{30}$ Menurut Fee, paling tidak ada lima persoalan yang ekseget modern hadapi, namun beruntung karena dua dekade terakhir dari abad ke-20 telah memperlihatkan berlimpahnya studi yang dipola untuk menuntun orang menangani masalah-masalah ini, jadi kita agak terbantu sekarang. Fee, New Testament Exegesis, 121.

${ }^{31}$ Osborne, Hermeneutical Spiral, 21.

${ }^{32}$ Berdasarkan lingkaran-lingkaran dari studi konteks yang mereka gambarkan, penyelidikan konteks justru dimulai dari lingkaran terdalam, yakni: konteks langsung, kemudian konteks keseluruhan kitab, dan baru konteks keseluruhan Alkitab. Introduction to Biblical Interpretation 2, 14-33.
} 
2. Pelajarilah setiap bagian secara intensif untuk melihat semua argumensi yang ada di dalamnya.

3. Susunlah kembali perkembangan pemikiran keseluruhan dalam hubungannya dengan bagian-bagian. $^{33}$

Prinsip utama yang sedang ditekankan Osborne dalam proses hermeneutik yang diusulkan di atas adalah penafsir bergerak dari keseluruhan kitab kepada bagian-bagian yang utama dari kitab tersebut dan kemudian kepada paragraf-paragraf dan terakhir kepada kalimatkalimatnya secara individu. Proses ini dijelaskan Osborne melalui sebuah contoh dari Kitab Filipi, sebuah contoh bahan didaktik atau pengajaran. ${ }^{34}$

Dalam bagan kitab Filipi yang dibuat, Osborne memberikan batas-batas yang menandai pembagian pokok-pokok utama. Tetapi bagaimana kita mengerti batas-batas ini? Ini sedikit sulit karena meskipun setiap perikop Alkitab memiliki suatu pengaturan yang memiliki makna, pola pemikiran sering kali tidak mudah ditemukan. Jadi, untuk mengenali pola-pola yang dapat dipakai sebagai indikator pembagian batas-batas tersebut Walter C. Kaiser menyediakan delapan petunjuk untuk menemukan "sambungan-sambungan" seperti ini di antara unit-unit pemikiran:

- Istilah-istilah, frasa, klausa atau kalimat yang diulang dapat berlaku sebagai awal untuk memperkenalkan setiap bagian atau sebagai kolofon (tanda akhir) untuk menyimpilkan masing-masing bagian.

- Sering kali ada petunjuk dari tata bahasa seperti konjungsi atau adverbia tradisional; misalnya, "kemudian, maka, oleh sebab itu, namun, akan tetapi, sementara itu," dan kata-kata Yunani oun, de, kai, tote, dio.

- Suatu pertanyaan retoris dapat menjadi tanda dari pergantian kepada suatu tema dan bagian yang baru. Mungkin juga akan ada serangkaian pertanyaan seperti ini yang membawa argumen atau rencana dari seluruh bagian.

- Suatu perubahan waktu, lokasi, atau latar merupakan alat yang sering dipakai, khususnya dalm konteks-konteks narasi, untuk menunjukkan suatu tema atau bagian yang baru.

- Suatu bentuk vokatif dari sapaan yang secara nyata menunjukkan suatu peralihan perhatian dari suatu kelompok kepada kelompok lain.

- Suatu perubahan dalam penanda waktu (sense), modus atau aspek dari verba, mungkin bahkan bersamaan dengan perubahan dalam subjek atau objek, dapat menjadi petunjuk lain bahwa suatu bagian yang baru sedang di mulai.

- Repetisi kata kunci, proposisi atau konsep yang sama bisa juga menunjukkan batasbatas dari suatu bagian.

- Dalam beberapa kasus, tema dari setiap bagian akan diumumkan sebagai judul bagi bagian itu. ${ }^{35}$

Tipe-tipe dasar dari batas-batas ini akan membantu penafsir ketika membaca sekilas paragrafparagraf dan merangkum isinya. Jadi, dengan menyadari kemungkinan-kemungkinan di atas, penafsir dapat memastikan suatu batas pemikiran tatkala mempersiapkan bagannya. Selain itu, batas-batas ini juga sangat membantu ketika penafsir memulai eksegesis yang lebih rinci.

\section{Membuat Diagram dari Paragraf}

Khusus pada bagian ini, kebanyakan penafsir atau mahasiswa teologi yang belum memiliki pengetahuan yang luas tentang bahasa Yunani mulai putus asa. Karena kalau

\footnotetext{
${ }^{33}$ Osborne, Hermeneutical Spiral, Ibid., 23-24.

${ }^{34}$ Ibid., 24.

${ }^{35}$ Walter C. Kaiser, Jr., Toward an Exegetical Theology: Biblical Principles for Preaching and Teaching (Grand Rapids: Baker, 1981), 71-72.
} 
bergantung kepada studi mandiri, penafsir bukan hanya kehabisan waktu, namun ini perlu pengetahuan yang cukup mendalam paling tidak tentang dasar-dasar bahasa Yunani. Untuk mengatasi rintangan ini, sudah tersedia diagram untuk seluruh surat Paulus diprogram komputer, yang dikenal dengan Bibleworks9. Namun karena keterbatasan ruang untuk menjelaskan teknik penggunaan dan cara pembacaan diagram tersebut dalam artikel ini, cukup hanya menjelaskan hal-hal yang penting saja.

Tujuan dan manfaat utama dari diagram tersebut adalah sebagian besar hubungan misalnya; adjektiva, nomina yang menerangkan, adverbia atau frasa-frasa preposisional yang menerangkan verba, cukup terlihat dari struktur klausa. Hal kedua adalah untuk menunjukkan alur pikiran suatu paragraf sesederhana mungkin.

Hal pertama yang harus dikerjakan dalam diagram kalimat adalah membedakan klausaklausa mayor dan minor. Klausa yang dimaksud adalah bagian dari kalimat yang mengandung satu subjek dan satu predikat. Misalnya; "Saya melihat kuda itu" (klausa utama atau mayor) atau "karena saya melihat kuda itu" (klausa subordinatif atau klausa minor). Apa perbedaan di antara keduanya? Klausa pertama dapat berdiri sendiri sebagai suatu kalimat, sementara klausa kedua tidak dapat. Jadi, tujuan keseluruhan dari membuat diagram adalah untuk memisahkan klausa mayor dan minor serta melihat bagaimana perkembangan alur pikiran di dalamnya.

\section{Mengkategorikan Jenis Retorika Teks}

Meski prinsip ini agak jarang dipakai dalam studi genre epistel, tetapi keberadaannya begitu terlihat jelas dalam surat-surat Paulus. Baru-baru ini Petrus Maryono secara khusus memperkenalkan studi tersebut sebagai salah satu usulan pendekatan penting dalam menganalisis Alkitab dengan mengangkat contoh retorika Paulus dalam Kisah Para Rasul. ${ }^{36}$

Rupanya orang-orang Yunani dan Romawi purba membedakan tiga jenis retorika utama, yakni: (1) Rerotika Judisial. Retorika sebagai usaha untuk meyakinkan suatu audiens tentang kebenaran atau kesalahan dari suatu tindakan di masa lalu. (2) Rerotika Delibratif. Retorika sebagai percobaan untuk mendesak orang-orang tertentu untuk melakukan sesuatu atau tidak melakukan sesuatu berdasarkan pertimbangan manfaat dari tindakan tersebut yang akan dilakukan di masa yang akan datang. (3) Retorika Epideiktik. Retorika melalui penggunaan pujian atau celaan untuk mendorong orang-orang mengafirmasi sebuah pandangan atau seperangkat konsep nilai di masa kini. ${ }^{37}$

Menurut G. A. Kennedy, sebuah penyampaian retorika yang lengkap mengandung semua fitur berikut, meskipun kadang-kadang satu atau lebih bagiannya tidak disertakan:

(1) Exordium. Menyatakan penyebab dan menarik perhatian dan simpati dari audiens. (2)

Narratio. Menghubungkan latar belakang dan fakta-fakta dari kasus yang ada. (3)

Propositio. Menyatakan apa yang telah disetujui dan apa yang telah ditolak. (4) Probotio.

Mengandung bukti-bukti berdasarkan kredibilitas dari sang pembicara; merangsang perasaan atau argumentasi logis dari para pendengar. (5) Refutatio. Menyangkal argumentasi-argumentasi dari para penentang. (6) Peroratio. Merangkum argumentasi dan berusaha meningkatkan emosi-emosi dari para pendengar. ${ }^{38}$

Dari surat-surat kiriman Perjanjian Baru, banyak di antaranya yang cukup dekat menyamai struktur di atas. Sebagai dasar untuk menggambarkan garis besar dari surat-surat Paulus, pemahaman di atas mampu membantu para penafsir memahami bagaimana tiap bagian dari sebuah surat menjalankan fungsinya. Sebagai contoh, F. W. Hughes mengidentifikasikan

\footnotetext{
${ }^{36}$ Petrus Maryono, Analisis Retoris: Suatu Teknik Studi Hermeneutik terhadap Teks Alkitab, peny., Daniel Yudianto (Yogyakarta: ANDI, 2017).

${ }^{37}$ Klein, Blomberg, Hubbard Jr., Introduction to Biblical Interpretation 2, 394.

${ }^{38}$ G. A. Kennedy, New Testament Interpretation through Rhetorical Criticism (Chapel Hill: University of North Carolina Press, 1984), 24.
} 
bahwa dalam 2 Tesalonika 2:1-2 mengandung sebuah tesis atau propositio yang atasnya keseluruhan surat dibangun - hari Tuhan tidak sesegera terjadi sebagaimana yang diajarkan dan dipercayai di dalam sejumlah gereja. ${ }^{39}$

Contoh lain disampaikan oleh H. D. Betz saat meneliti Galatia 3-4. Menurut Betz, Galatia 3-4 mengumpulkan bukti-bukti (probatio) untuk mendukung pengajaran Paulus tentang dibenarkan oleh iman dalam pasal 2:15-21. Semua bukti yang dikumpulkan tersebut mengungkapkan keragaman argumentasi yang dapat diterapkan oleh seorang penulis atau pembicara masa purba dalam usahanya untuk meyakinkan orang lain, yang juga merupakan strategi-strategi yang tetap dapat kita gunakan secara efektif pada masa kini. Bukti-bukti yang ditampilkan di antaranya mencakup argumentasi-argumentasi yang berasal dari: pengalaman pribadi yang tak terbantahkan (penerimaan Roh Kudus oleh orang-orang Galatia, 3:1-5 versus kehidupan mereka dahulu sebagai orang-orang non-Kristen, 4:8-11); Kitab Suci (Kej. 15:6; Kej. 12:3; Ul. 27:26; Hab. 2:4; Im. 18:5; dan Ul. 21:23 dalam Galatia 3:6-14); praktik umum umat manusia (dalam membuat perjanjian, menjaga para tahanan, dan memberikan harta warisan, 3:15-18, 21-22; 4:1-7); tradisi Kristen (khususnya dalam baptisan, 3:26-29); persahabatan (4:1220); dan sebuah analogi (dengan pembuatan perjanjian Abraham, 4:21-31). ${ }^{40}$

Jadi, ketika hendak menganalisis surat-surat Paulus, diharapkan seorang penafsir menentukan jenis retorika apa yang dipakai. Memang menjadi rumit ketika Paulus mencampuradukkan dua atau tiga jenis retorika yang ada. Tetapi, hampir semua surat-suratnya dirancang dengan fungsi khusus, karena tujuan utamanya adalah memberitahukan bagaimana para orang percaya harus bertindak atau tidak bertindak.

\section{Melakukan Studi Semantik}

Studi semantik merujuk kepada studi untuk menentukan makna kata di mana makna adalah inti dari komunikasi. Akhir-akhir ini semantik lebih merupakan suatu seni ketimbang ilmu. ${ }^{41}$ Hal ini sangat penting karena kata adalah suatu kombinasi dari bunyi-bunyi atau hurufhuruf yang mewakili suatu konsep tertentu. ${ }^{42}$ Dalam melakukan studi semantik, ada tiga prinsip mendasar yang diusulkan.

\section{Tentukan Kata-kata Kunci yang Membutuhkan Penyelidikan}

${ }^{39}$ F. W. Hughes, Early Christian Rhetoric and 2 Thessalonians, JSNTSup 30 (Sheffield: JSOT, 1989), 56-

57).

${ }^{40}$ H. D. Betz, Galatian, Hermeneia (Philadelphia: Fortress, 1989), 19-22, sejumlah istilah yang dipakainya telah dimodifikasi.

${ }^{41}$ Johannes Louw mengatakan bahwa sejak tahun 1950-an studi kata dan makna katanya telah menjadi perhatian utama di kalangan akademik, Semantics of New Testament Greek (Philadelphia: Fortress, 1982), 1-4. Sejak abad kedua puluh semantik telah benar-benar diakui sebagai ilmu linguistik yang dapat berdiri sendiri. Untuk mengetahui cara menerapkan prinsip-prinsip linguistik ini secara ilmiah dalam studi Alkitab, lihat karya monumental James Barr, The Semantics of Biblical Language (Oxford: Oxford University Press, 1961). Untuk survei historis yang baik, lihat David Alan Black, "The Study of New Testament Greek in the Light of Ancient and Modern Linguistic," dalam Interpreting the New Testament: Essay on Methods and Issues, peny., D. A. Black and D. S. Dockery (Nashville: Broadman \& Holman, 2001), 230-52.

${ }^{42}$ Untuk mendapatkan bantuan yang lebih rinci dalam kaitan dengan seluk-beluk studi kata-kata modern, khususnya dalam terang studi linguistik, lihat P. Cotterell dan M. Turner, Linguistics and Biblical Interpretation (Downers Grove: InterVarsity, 1989); Moisés de Silva, Biblical Words and Their Meaning: An Introduction to Lexical Semantics (Grand Rapids: Zondervan, 1995); J. P. Louw, Semantics of New Testament Greek (Philadelphia: Fortress, 1982); E. A Nida dan J. P. Louw, Lexical Semantics of the Greek New Testament (Atlanta: Scholars, 1992). 
Tidak semua kata yang ada di dalam sebuah perikop butuh penyelidikan. Penafsir harus memiliki kepekaan terhadap istilah-istilah yang menonjol di dalam suatu konteks jika itu memerlukan penyelidikan lebih lanjut. Fee memberi empat langkah yang dapat membantu penafsir dalam menentukan kata-kata kunci yang perlu dianalisis, sebagai berikut:

Pertama, perhatikan istilah-istilah dalam konteks yang "memiliki muatan teologis." Jika

Anda menemukan istilah-istilah yang menyatakan kebenaran-kebenaran dasar dari Perjanjian Baru (seperti "anugerah," "Tuhan" atau "keselamatan"), istilah ini pasti memerlukan studi lebih lanjut. Kedua, perhatikan kata mana saja yang dengan jelas memberikan pengertian yang berbeda dalam teks, yang tampaknya bermakna ganda atau tidak jelas. ... Ketiga, perhatikan kata yang diulang-ulang dalam satu konteks atau menjadi tema di dalam suatu paragraf harus diselidiki. Contoh, istilah "bersukacita" dalam Filipi. . . Keempat, perhatikan istilah-istilah yang lebih signifikan dalam konteksnya ketimbang yang diperkirakan sebelumnya. ${ }^{43}$

Dari empat langkah yang diusulkan Fee di atas, dapat diartikan bahwa pemahaman yang tepat pada banyak bagian akan bergantung pada analisis yang cermat mengenai kata-kata.

\section{Perhatikan Konteks Tempat Kata Muncul}

Izinkan konteks untuk menentukan makna yang paling cocok dengan berita yang dimaksudkan secara menyeluruh. Pernyataan ini ditegaskan oleh Silva di mana "konteks tidak hanya menolong kita memahami makna; kontekslah yang menghasilkan makna." ${ }^{44}$ Tanpa memperhatikan konteks maka penafsiran sudah gagal dari awal. Mengapa demikian? Karena pernyataan-pernyataan benar-benar tidak memiliki makna jika terlepas dari konteks mereka. Sebagai contoh, jika saya mengatakan "berikan itu kepada saya," maka Anda akan langsung bertanya, "Apa maksud Anda dengan itu?" dan "Bagaimana saya melakukannya?" Artinya, jika Anda tidak mengerti situasi dan isi perintah itu, maka perintah tersebut menjadi tidak bermakna. Di dalam Kitab Suci, konteks menyediakan situasi di balik teks. Dan faktanya, tidak ada makna di luar konteks.

Atas dasar pertimbangan di atas, Zuck akhirnya menyarankan agar seorang penafsir jangan bergantung mutlak kepada etimologi kata untuk menentukan makna kata. Praktik yang lebih baik adalah melihat penggunaan kata tersebut oleh orang yang mengatakannya atau cara si penulis kitab menggunakan kata itu dalam konteksnya. ${ }^{45}$ Ini terutama penting karena sebuah kata mengandung makna-makna yang berbeda, tergantung bagaimana kata tersebut digunakan. Misalnya, kata dipanggil digunakan paling tidak dalam dua cara. Dalam Injil Sinoptik "panggilan" Allah berarti undangan-Nya, namun ketika dipakai Paulus istilah tersebut merujuk kepada tindakan Allah memberi kepadanya gelar dan tugas ("dipanggil menjadi rasul” Rm. 1:1), atau karya Allah dalam memberi keselamatan kepada orang-orang percaya (Rm. 8:28, 30), atau undangan Allah kepada orang-orang percaya dengan dorongan yang kuat ("memanggil kita dengan panggilan kudus," 2 Tim. 1:9). Intinya, perhatikan penggunaan kata-kata itu oleh penulis dan konteks langsungnya sering kali (meskipun tidak selalu) dapat membantu menentukan makna dari sebuah kata. Jadi penting sekali untuk memperhatikan beberapa jenis penggunaan kata.

\section{Tentukan Jangkauan Makna dari suatu Kata}

\footnotetext{
${ }^{43}$ Fee, New Testament Exegesis, 84-85.

${ }^{44}$ Moisé de Silva, Biblical Word and Their Meaning: An Introduction to Lexical Semantics (Grand Rapids: Zondervan, 1983), 139.

${ }^{45}$ Zuck, Basic Bible Interpretation, 103-104.
} 
Prinsip utama di sini adalah penafsir menentukan jangkauan makna dari suatu kata penting dalam konteksnya sekarang ini. Artinya, hal terpenting bagi penafsir adalah menyelidiki bagaimana suatu kata digunakan pada waktu penulisan, ketimbang bagaimana suatu kata dikembangkan pada waktu sebelumnya. Kesalahan umum yang kerap dilakukan dan kadang tidak disadari para penafsir adalah terlalu asik dengan etimologi kata (akar kata) saja dengan melihat kamus-kamus, sehingga menduga bahwa itulah arti kata tersebut. Etimologi tetap menolong tetapi sampai batas-batas tertentu.

Misalnya saja kata Yunani ekklesia yang diterjemahkan menjadi "gereja" yang berasal dari dua dua suku kata, yakni kata $e$ ("keluar dari") dan kalein ("memanggil atau mengumpulkan”). Sehingga dalam Perjanjian Baru kata ekklesia merujuk kepada orang-orang yang dipanggil keluar dari antara orang-orang yang belum diselamatkan ke dalam sekelompok orang percaya. Tetapi kadang-kadang di dalam perkembangannya, sebuah kata mengambil makna yang sama sekali berbeda dari makna aslinya. Dengan demikian, akar kata (etimologi) tidak bisa dijadikan pedoman utama, karena makna kata berubah.

Contoh yang lain misalnya, kata eirēnē dalam bahasa Yunani pada mulanya berarti perdamaian dari perang, kemudian maknanya bergeser menjadi ketenangan pikiran, kemudian menjadi kesejahteraan, dan kerap digunakan untuk menyebutkan hubungan yang benar dengan Allah. Jadi, dengan mempertimbangkan perkembangan makna kata seperti di atas, James Barr akhirnya menyimpulkan bahwa "etimologi kata bukanlah pernyataan tentang maknanya, tetapi tentang sejarahnya." ${ }^{46}$ Intinya, etimologi dari sebuah kata sering tidak dapat membantu menentukan maknanya. Oleh karena itu kita perlu mengetahui penggunaannya di masa kini yang telah ditetapkan penulisnya.

Contoh lainnya misalnya kata Yunani sarx (daging) mungkin memiliki arti berikut: (a) bagian padat tubuh kecuali tulang (1 Kor. 15:39); (b) seluruh substansi tubuh (Kis. 2:26); (c) sifat jasmani manusia (Kol. 2:18); dan (d) sifat manusia yang didominasi oleh keinginan dosa (Rm. 7:18). Jika semua makna ini diterapkan pada kata-kata sebagaimana ditemukan dalam Yohanes 6:53, di mana Kristus berbicara tentang daging-Nya sendiri, maka kesimpulan penafsir akan mengenakan dosa pada Kristus. Tanpa melihat konteks, kesimpulan akhir bisa salah jika hanya mengandalkan makna etimologis.

Singkatnya, etimologi memiliki nilai yang terbatas, namun kadang kala dapat sangat membantu konteks. Secara tepat Thiselton menyimpulkan bahwa istilah atau etimologi itu sendiri bukan merupakan unit dasar dari makna. Makna dari satu kata tidak bergantung pada dirinya sendiri, melainkan pada hubungan kata itu dengan kata-kata lain dan dengan kalimatkalimat lain yang membentuk konteksnya." 47 Dengan kata lain, berpikir secara konteks memegang peranan penting dan sangat membantu menentukan jangkauan makna sebuah kata. Artinya, penggunaan-penggunaan kata tersebut oleh penulisnya dalam tulisan-tulisannya yang lain harus menjadi pertimbangan utama ketimbang arti kata tersebut pada bagian lain dalam Perjanjian Baru.

Jadi, hati-hati dalam menyimpulkan makna dari sebuah kata. Jangan langsung menentukan makna dari kata itu dengan melihat arti kamusnya atau akar katanya. Akar satu kata akan berfungsi untuk memberikan semacam "panduan kasar kepada kemungkinan makna dari kata-kata yang tidak di kenal," tetapi tidak selalu berarti bahwa kata-kata yang seasalnya mengusung suatu arti dasar yang sama. Intinya, makna bergantung konteksnya dalam kalimat. Jadi, selidikilah rentang arti kata tersebut bagi penulisnya sendiri di kala ia menulis.

Dalam studi ini leksikon karya Bauer-Arndt-Gingrich-Danker (BDAG, 1979) sangat bermanfaat, karena leksikon ini melacak asal mula dan distribusi suatu istilah dan juga

${ }^{46}$ James Barr, The Semantics of Biblical Language (Oxford: Oxford University Press, 1961), 109. Lihat juga Darrell L. Bock, "New Testament Word Analysis," dalam Introducing New Testament Interpretation (Grand Rapids: Baker Book House, 1989), 97-113.

${ }^{47}$ Anthony C. Thiselton, "Semantics and New Testament Interpretation," dalam New Testament Interpretation, peny., I. Howard Marshall (Grand Rapids: Eerdmans, 1977), 78-79. 
jangkauan makna dasarnya. Akan tetapi jangan menganggap keputusan-keputusan BAGD sebagai keputusan yang tidak dapat dibantah. ${ }^{48}$ Leksikal seperti TDNT atau NIDNTT juga merupakan sarana-sarana yang baik, tetapi ini bukan dimaksudkan untuk studi leksikal secara mendetail dan tidak menyeluruh dalam hal jangkauan makna, karena karya ini lebih berkenaan dengan penggunaan teologis.

\section{Menyelidiki Gramatikal}

Tujuan akhir penyelidikan gramatika adalah tersingkapnya makna teks seperti yang dimaksudkan oleh penulis awal. Namun, karena keterbatasan waktu, penafsir harus menyelidiki kata-kata yang penting saja. Jangan membiarkan karya tersebut menjadi sebuah koleksi katakata saja. Untuk memanfaatkan waktu yang ada, pilihlah untuk menyelidiki kata-kata tertentu atas dasar dua kriteria: (1) Jelaskan apa yang kurang dimengerti; (2) Fokuslah pada kata-kata kunci dan susunan kata-katanya. Saat memulai penyelidikan gramatika, buatlah daftar mengenai kata-kata kunci dan ungkapan-ungkapan yang muncul berulang kali yang menunjukkan persoalan utama dari bagian itu. Dalam penyelidikan gramatika, ada beberapa unsur penting yang perlu diperhatikan secara khusus. Namun dalam artikel ini hanya dibahas secara terbatas dan singkat saja mengenai sistem verba dan nomina.

\section{Selidiki Sistem Verba}

Dalam bahasa Yunani verba menekankan tentang tindakan atau keadaan. Dalam sistem verba, ada tiga unsur penting yang harus menjadi fokus penyelidikan, yakni: unsur tense (kala); unsur modus; dan unsur diatesis.

\section{Amati Unsur Tense (kala) Kata Kerjanya}

Karena unsur kala yang sangat penting dalam bahasa Yunani, maka ketika menyelidiki sebuah kata kerja dalam kalimat, perhatikan unsur tenses (kala) kata kerja tersebut. Secara umum, kala bahasa Yunani melibatkan dua unsur utama, yakni: aspek (jenis tindakan) dan waktu tindakan verba terjadi. Namun dalam bahasa Yunani, aspek menjadi unsur utama, sedangkan waktu merupakan unsur sekunder (jika hal itu terlibat). ${ }^{49}$ Yang dimaksud dengan aspek adalah "cara penggambaran tindakan berkenaan dengan kelangsungannya." Ketika menyelidiki aspek tindakan apa yang kira-kira dijelaskan dalam kata kerja, hanya ada tiga kemungkinan yang terjadi: (1) "Tindakan berlangsung" kadang disebut tindakan linier, duratif, iteratif, atau belum rampung, yang termasuk katagori ini adalah kala kini, imperfek, dan future. (2) "Tanpa penjelasan" di mana yang ditekankan hanya soal keberadaan atau munculnya tindakan. Yang termasuk golongan ini adalah aoris dan future. (3) "Tindakan rampung" di mana tindakan telah diselesaikan (perfektif), dan dampaknya masih ada. Kategori ini perfek dan pluperfek. $^{50}$

Dalam penyelidikan terhadap unsur waktu tekanannya menjelaskan tentang kapan tindakan itu terjadi. Dalam bahasa Yunani tindakan dibedakan dalam tiga bentuk waktu, yakni;

\footnotetext{
${ }^{48}$ Penting untuk diingat bahwa BAGD bersifat deskriptif dan menafsirkan. Ketika BAGD menempatkan satu perikop di belakang satu makna tertentu, maka itu merupakan suatu pendapat dan bukan suatu fakta yang sudah terbukti.

${ }^{49}$ Petrus Maryono, Gramatika \& Sintakis Bahasa Yunani Perjanjian Baru (Yogyakarta: STTII Yogyakarta, 2016), 124.

${ }^{50}$ Ibid., 125
} 
bentuk lampau (aorist); kini (present), atau akan (future). Dalam unsur waktu, modus akan menjadi penentu. Mengenai penjelasan unsur ini Maryono memaparkannya demikian,

Dalam modus indikatif unsur waktu bersifat mutlak. Namun dalam hal ini pun unsur aspek masih jauh lebih menentukan. Sedangkan dalam modus subjungtif, optatif, dan imperatif, secara intrinsik unsur waktu terlibat. Kalau unsur waktu terlibat juga, kontekslah faktor penentunya. Sedangkan dalam partisip dan infinitif sifatnya relatif; waktu akan ditentukan berdasarkan hubungannya dengan waktu tindakan kata kerja pokok. ${ }^{51}$

\section{Amati Unsur Modus Kata Kerjanya}

Dalam penyelidikan terhadap unsur modus, ada empat sikap penegasan yang diselidiki, yakni: indikatif, subjungtif, imperatif dan optatif. Jadi, modus menandakan jenis tindakan, sementara tenses (kala) menandakan waktu tindakan. Sebagai contoh misalnya "James berdoa" adalah sebuah pernyataan (modus indikatif). "Apakah James berdoa?" (modus interogatif). "James, berdoalah" (adalah sebuah perintah (modus imperatif). "James tolong berdoalah" (modus optatif). Jadi, dalam program Bibleworks 9 setiap kata kerja telah ditunjukan modusnya, namun ekseget tetap perlu memutuskan fungsi apa yang tepat dari penggunaan modus tersebut. Keputusan ini bisa dibuat dengan bantuan karya Daniel B. Wallace, Greek Grammar Beyond the Basics: An Exegetical Syntax of the New Testament (Grand Rapids: Zondervan Publishing House, 1996) dan Petrus Maryono, Gramatika \& Sintaksis Bahasa Yunani Perjanjian Baru (Yogyakarta: STTII Yogyakarta, 2016).

\section{Amati Unsur Diatesis Kata Kerjanya}

Penyelidikan terhadap unsur diatesis penekanannya pada hubungan subjek dengan lakunya. Dalam hal ini hanya ada tiga kemungkinan, apakah tindakan itu bersifat aktif, pasif, atau medial. Misalnya; "Allah mengirimkan Anak-Nya" kata kerja "mengirimkan" mempunyai diatesis aktif. Jika kalimatnya adalah "Anak dikirim oleh Allah" kata kerja "dikirim" mempunyai diatesis pasif. Tetapi jika kalimatnya adalah "Allah mengirim bagi diri-Nya sendiri" maka sudah berubah menjadi diatesis medial.

Agar bisa melakukan penyelidikan sistem verba dan fungsi-fungsinya seperti yang dijelaskan di atas, ada beberapa alat bantu gramatika yang sangat baik saat ini. Seperti: Daniel B. Wallace, Greek Grammar Beyond the Basics: An Exegetical Syntax of the New Testament (Grand Rapids: Zondervan Publishing House, 1996); H. E. Dana dan Julius R. Mantey, A Manual Grammar of the New Testament (Toronto: Collier-MacMillan, 1957); William D. Chamberlain, An Exegetical Grammar of the Greek New Testament (Grand Rapids: Baker Book House, 1988); Petrus Maryono, Gramatika \& Sintaksis Bahasa Yunani Perjanjian Baru (Yogyakarta: STTII Yogyakarta, 2016).

\section{Selidiki Sistem Nomina}

Nomina adalah kata atau sekelompok kata yang digunakan untuk menyebut tempat, manusia, benda atau apa yang dibendakan. Setiap kata benda (nomina) Yunani mengandung tiga unsur pokok: jumlah, jenis, dan kasus. Ketiga unsur ini memiliki peran penting untuk menandai fungsi nomina di dalam kalimat.

\footnotetext{
${ }^{51}$ Ibid., 124.
} 


\section{Amati Unsur Jumlah Nominanya}

Dalam unsur jumlah, nomina Yunani hanya dibedakan dalam dua jenis jumlah: tunggal dan jamak. Dengan bantuan tools yang tersedia saat ini (mis., Bibleworks9), tidak lagi sulit untuk mengetahui apakah nomina ini berjumlah tunggal atau jamak. Tinggal mengarahan kursor di atas kata benda yang diselidiki, maka jumlah akan muncul dengan sendirinya.

\section{Amati Unsur Jenis Nominanya}

Dalam unsur jenis, nomina Yunani dibedakan ke dalam tiga jenis: maskulin, feminin, dan netral. Dalam program Bibleworks9, semua kata yang tergolong dalam famili nomina juga secara otomatis akan muncul kata-kata; masculine, feminine, neuter.

\section{Amati Unsur Kasus Nominanya}

Sedangkan dalam unsur kasus, nomina Yunani menggunakan perubahan bentuk (disebut infleksi) yang berbeda-beda, yakni: nominatif, genitif, datif, akusatif, dan vokatif. Dan masing-masing kasus ini juga mempunyai sejumlah kemungkinan fungsi sintaksis. Dalam program Biblework9 juga sudah ditunjukkan bentuk nomina sebuah kata, apakah kata itu mengambil bentuk kasus nominatif, genitif, datif, atau bentuk lainnya. Tetapi, tidak menjelaskan apa-apa tentang fungsi sintaksis dari setiap kasus tersebut, pada hal dalam penyelidikan gramatikal penyelidikan fungsi ini memegang peran yang sangat penting. Nampaknya, keputusan untuk menentukan fungsi apa yang sesuai dengan kasusnya diserahkan sepenuhnya kepada keputusan seorang ekseget.

Khusus dalam melakukan penyelidikan fungsi kasus nominatif genitif, datif, akusatif, dan vokatif, alat bantu yang sangat penting adalah karya Daniel B. Wallace, Greek Grammar Beyond the Basics: An Exegetical Syntax of the New Testament (Grand Rapids: Zondervan Publishing House, 1996) dan Petrus Maryono, Gramatika \& Sintaksis Bahasa Yunani Perjanjian Baru (Yogyakarta: STTII Yogyakarta, 2016).

\section{Menyelidiki Penggunaan Perjanjian Lama dalam} Perjanjian Baru

Khusus mengenai kutipan dalam tulisan Paulus, Moisés Silva menggabungkan beberapa survei tentang kutipan-kutipan Paulus, mencapai jumlah 107, dengan 42 kutipan mencerminkan baik LXX maupun Masoret Teks, 7 kutipan lebih mencerminkan Masoret Teks ketimbang LXX, 17 kutipan lebih mencerminkan LXX ketimbang Masoret Teks, 31 terjemahan bebas yang tidak mengikuti keduanya, dan 10 kutipan masih diperdebatkan. ${ }^{52}$ Christoper Stanley memperkirakan bahwa 60 persen dari kutipan Paulus disesuaikan dengan kebutuhan dari konteksnya. ${ }^{53}$

\footnotetext{
${ }^{52}$ M. Silva, "Old Testament in Paul," dalam Dictionary of Paul and His Letters, peny., G. F. Hawthorne, R. P. Martin, dan D. G. Reid (Downers Grove: Ill.: InterVarsity, 1993), 631. Daftar ini mencakup epistel-epistel yang meragukan. D. M. Smith, "The Pauline Literature," dalam It Is Written: Scripture Citing Scripture; Essays in Honor of Barnabas Lindars, peny., D. A. Carson dan H. G. M. Williamson (Cambridge: Cambridge University Press, 1988), 267-76; mengutip lebih sedikit dibandingkan Silva, yakni ada kira-kira 100 kutipan yang mayoritas, sampai tahap tertentu, berasal dari sebuah teks Perjanjian Lama yang paling menyerupai Septuaginta Yunani.

${ }^{53}$ Christopher D. Stanley, "The Social Enverionment of 'Free' Biblical Quotations in the New Testament," dalam Early Christian Interpretation of the Scriptures of Israel: Investigation and Proposals, peny., Craig A. Evans dan James A. Sanders (Sheffield, U.K.: Academic Press, 1989), 19. Ia berpendapat bahwa dalam dunia kuno, para
} 
Dari fakta ini, ada empat kesimpulan penting yang bisa ditarik: (1) Para penulis Perjanjian Baru memperlihatkan kepercayaan mereka terhadap otoritas Perjanjian Lama. Tidak ada seorang penulis Perjanjian baru yang meragukan atau tidak mengakui kebenaran bagian dari Perjanjian Lama; (2) penggunaan Perjanjian Lama yang begitu luas jelas menandakan bahwa kedua Perjanjian itu saling berhubungan secara organik; (3) khusus mengenai Paulus, jelas bahwa ia sudah terbiasa dengan Alkitab Ibrani dan LXX dan dapat menggunakan keduanya dengan ahli; dan (4) ini menandakan bahwa dalam menginterpretasikan Perjanjian Baru, para ekseget Alkitab tidak dapat mengabaikan Perjanjian Lama.

Ulasan mengenai pokok ini perlu dibatasi, sebab sebenarnya ini bisa dijadikan prosedur tersendiri, karenanya hanya dipaparkan secara sekilas di sini. Di bawah ini ada beberapa prosedur yang dapat diusulkan untuk menganalisis penggunaan Perjanjian Lama dalam tulisantulisan Paulus.

\section{Selidiki Kutipan Langsung oleh Paulus}

Definisi kutipan yang kita gunakan di sini merujuk kepada definisi Beale, yakni sebagai "petikan langsung dari sebuah perikop Perjanjian Lama yang dengan mudah dapat dikenali melalui paralelisme lisannya yang jelas dan unik." ${ }^{54}$ Untuk menentukan apakah kutipan ini bersifat langsung, ada dua cara yang bisa terlihat; pertama, terlihat dari fomula dan terlihat dari variasi pengalimatan dalam kutipan.

Pertama, dari unsur formula, banyak kutipan Paulus yang didahului dengan sebuah formula, misalnya, "seperti ada tertulis" (Rm. 3:4), "Kalau hukum Taurat tidak mengatakan" (Rm. 7:7), "Itulah sebabnya dikatakan" (Ef. 5:14), "Bukankah Kitab Suci berkata” (1 Tim. 5:18), atau ekspresi serupa lainnya. Petikan-petikan lainnya tanpa indikator pengantar semacam itu tampak begitu jelas dikuti oleh Paulus dari sebuah teks Perjanjian Lama, misalnya seperti dalam Galatia 3:6 dan Efesus 6:3. Kebanyakan komentator setuju atas sebagian besar dari apa yang harus diakui sebagai kutipan yang berasal dari Perjanjian Lama. ${ }^{55} \mathrm{Jadi}$, saat menyelidiki teks, perhatikan apakah muncul formula-formula seperti di atas.

Kedua, selidiki apakah telah terjadi variasi pengalimatan dalam kutipan Paulus dalam teks tersebut. Dalam mengutip Perjanjian Lama, para penulis Perjanjian Baru sering mengubah atau menghilangkan kata-kata. Mereka menggunakan kebebasan dalam mengubah-ubah pokokpokok tata bahasa, dalam parafrasa, menghilangkan bagian-bagian tertentu, melakukan kutipan sebagian, menggunakan sinonim, dan mengakui aspek-aspek kebenaran yang baru. ${ }^{56}$

ahli tulis diharapkan menjadi pengomentar dan bukan hanya penyalin, jadi adaptasi seperti ini merupakan bagian darikeadaan sosial.

${ }^{54} \mathrm{G}$. K. Beale, Handbook on the New Testament Use the Old Testament - Exegesis and Interpretation (Grand Rapids: Baker Academic, 2012), 35; S. E. Porter, "Further Comments on the Use of the Old Testament in the New Testament," dalam The Intertextuality of the Epistles: Explorations of Theory and Practice, peny., T. L. Brodie, D. R. MacDonald, dan S. E. Porter, NTM 16 (Sheffield: Sheffield Phoenix, 2007), 107-9, mengkategorikan "kutipan langsung" ke Perjanjian Lama sebagai kutipan resmi (dengan suatu formula pendahuluan), kutipan tidak resmi (yang harus mempunyai paling sedikit tiga kata yang sama dengan rujukan Perjanjian Lama), dan "parafrase" (yang mempunyai cukup kata-kata unik sehingga dapat diamati adanya kaitan dengan teks Perjanjian Lama yang dapat dikenali).

${ }^{55} \mathrm{C}$. A. Beetham, Echoes of Scripture in the Letter of Paul to the Colossian, Biblical Interpretation 96 (Boston: Brill, 2008), 15-17; untuk pembahasan oleh berbagai akademisi mengenai natur dan definisi sebuah kutipan, lihat S. E. Porter, "The Use of the Old Testament in the New Testament: A Brief Comment on Method and Terminology," dalam Early Christian Interpretation of the Scriptures of Israel, peny., C. A. Evans dan J. A. Sanders, JSNTSup 148, SSEJC (Sheffield: Sheffield Academic Press, 1997), 79-96.

${ }^{56}$ Untuk mengetahui berbagai contoh mengenai variasi pengalimatan para penulis Perjanjian Baru yang sering mengubah atau menghilangkan kata-kata ketika mengutip Perjanjian Lama, lihat, Zuck, Basic Bible Interpretation, 254-270. 


\section{Selidiki Teknik Alusi-alusi oleh Paulus}

Definisi alusi yang dimaksud adalah "sebuah ungkapan singkat yang secara sadar dimaksudkan oleh seorang penulis untuk bergantung pada suatu perikop Perjanjian Lama ... yang merupakan referensi tidak langsung (penyusunan kata-kata Perjanjian Lama tidak direproduksi secara langsung seperti halnya kutipan)." ${ }^{, 57}$

Karena alusi bersifat referensi tidak langsung atau kutipan tidak resmi oleh penulis Perjanjian Baru, maka tidak ada formula baku mengenai alusi. Namun, ada beberapa pakar mengusulkan alusi harus terdiri dari reproduksi perikop Perjanjian Lama yang mengandung kombinasi unik paling sedikit tiga kata yang sama. ${ }^{58}$ Kriteria-kriteria sebuah alusi dalam tulisantulisan Paulus yang disajikan di sini adalah kriteria yang ditawarkan oleh Richard Hays. Namun, dari tujuh kriteria yang ia usulkan, hanya lima yang diungkap di sini, karena dua kriteria terakhir (kriteria "sejarah penerjemahan" dan "kepuasan") diakui sendiri merupakan standar evaluatif yang tidak terlalu kuat. Kriteria-kriteria tersebut adalah sebagai berikut:

(1) Ketersediaan. Teks sumber (Perjanjian Lama bahasa Yunani maupun Ibrani) harus tersedia bagi penulis. Penulis tentunya berharap pendengar pertama atau pembaca berikutnya dapat mengenali alusi yang dimaksud.

(2) Isi. Ada tingkat pengulangan kata demi kata yang signifikan atau pola-pola yang bersifat sintaksis.

(3) Pengulangan Kejadian. Ada referensi dalam konteks langsung (atau di mana pun oleh penulis yang sama) yang merujuk ke konteks Perjanjian Lama yang sama tempat alusi itu berasal.

(4) Koherensi Tematik. Alusi Perjanjian Lama tersebut sangat tepat dan memuaskan jika maknanya dalam Perjanjian Lama tidak cocok secara tematik dengan argumentasi penulis Perjanjian Baru, tetapi juga mengiluminasi bagian itu.

(5) Kewajaran Historis. Ada kewajaran bahwa penulis Perjanjian Baru memaksudkan alusi semacam itu dan pendengarnya memahami penggunaannya oleh penulis Perjanjian Baru sehingga berbagai tahapan, khususnya pada pembacaan surat-surat yang berikutnya. ${ }^{59}$

Meskipun beberapa pakar bersikap kritis terhadap metodologi yang diusulkan di atas, ${ }^{60}$ namun menurut Beale, pendekatan Hays di atas merupakan salah satu cara terbaik untuk mencermati dan membahas natur serta validitas alusi (meskipun dia menyukai istilah "gema"). ${ }^{61}$

\section{Identifikasikan Referensi Perjanjian Lama di mana Kutipan dan Alusi Muncul}

\footnotetext{
${ }^{57}$ Beale, Handbook on the New Testament Use the Old Testament, 38. Beberapa akademisi menggunakan istilah "alusi" dengan "gema" hampir secara sinonim. Lihat, misalnya; Richard Hays, Echoes of Scripture in the Letter of Paul (New Haven: Yale University Press, 1989), 18-21, 30-31, 119.

${ }^{58}$ S. E. Porter, "Further Comments on the Use of the Old Testament in the New Testament," dalam The Intertextuality of the Epistles: Explorations of Theory and Practice, peny., T. L. Brodie, D. R. MacDonald, dan S. E. Porter, NTM 16 (Sheffield: Sheffield Phoenix, 2007), 107-9.

${ }^{59}$ Hays, Echoes of Scripture in the Letter of Paul, 29-32.

${ }^{60}$ Porter adalah salah satu kritikus terkemuka yang tidak setuju dengan pandangan Hays di atas. Ia menyatakan bahwa kriteria tersebut bersifat kontradiktif dan beberapa kriteria itu bersifat eksklusif terhadap yang lain. S. E. Porter, “Allusion and Echoes," dalam As It Is Written: Studying Paul's Use of Scripture, peny., S. E. Porter dan C. D. Stanley, SLB Symposium Series 50 (Atlanta: Society of Biblical Literature, 2008), 29-40. Untuk meninjau para akademisi yang mendukung dan tidak mendukung pendekatan Hays, lihat Kenneth D. Litwak, "Echoes of Scripture" A Critical Survey of Recent Works on Paul's Use of the Old Testament," dalam Currents in Biblical Research 6 (1998): 260-88.

${ }^{61}$ Beale, Handbook on the New Testament Use the Old Testament, 41.
} 
Untuk mengidentifikasi referensi Perjanjian Lama yang muncul dalam kutipan atau alusi tulisan Paulus, ada beberapa sumber terkini yang sangat bermanfaat dalam melakukan kajian tersebut, di antaranya adalah $\mathrm{NA}^{27},{ }^{22} \mathrm{UBS}^{4},{ }^{63}$ Alkitab terjemahan terstandar, ${ }^{64}$ beberapa buku, ${ }^{65}$ dan materi terakhir adalah konkordansi. ${ }^{66}$

\section{Selidiki Makna Asli dan Konteks Ayat Perjanjian Lama di mana Kutipan atau Alusi itu Muncul}

Ekseget yang baik harus menganalisis terlebih dahulu, apa makna asli teks Perjanjian Lama yang dikutip Paulus, sebelum meneliti apa yang dilakukan penulis tersebut terhadap teks Perjanjian Lama yang ia kutip. Kita perlu mengetahui bagaimana perikop tersebut digunakan secara asli sebagai kendali bagi penggunaannya di dalam konteks-konteks selanjutnya. Ada satu diktum hermeneutika yang penting ditekankan oleh Dodd tatkala ia mengatakan bahwa "suatu kutipan atau alusi sering mengasumsikan konteks asli Perjanjian Lama di balik alusi dan bukan hanya alusi itu sendiri." ${ }^{67}$

\section{Selidiki Tujuan Kutipan atau Alusi Perjanjian Lama Oleh Paulus}

Dalam dunia penulisan, orang sering kali mengutip tulisan-tulisan orang lain karena tujuan dan alasan-alasan tertentu, misalnya; untuk menunjang gagasan pokok mereka, memberi contoh atau gambaran yang memperjelas sebuah ide atau maksud tertentu, atau mungkin membuat perbanding tulisannya dengan karya orang lain, dan lain sebagainya. Demikian pula halnya dengan para penulis Perjanjian Baru yang mengutip Perjanjian Lama memiliki tujuan dan alasan tertentu dibalik pengutipan tersebut. Ketika menyelidiki apa motif Paulus saat menggunakan kutipan atau alusi dalam tulisannya, pertimbangkan beberapa daftar usulan para

${ }^{62}$ Ini adalah edisi ke-27 dari buku karya Nestle-Aland $\left(\mathrm{NA}^{27}\right)$, Novum Testamentum Graece, yang diedit oleh B. Aland, K. Aland, J. Karavidopoulos, C. M. Martini, dan Bruce M. Metzger (Stuttgart: Deutsche Bibelgesellschaft, 1993). Para editor ini telah menempatkan sebuah referensi Perjanjian Lama di margin luar dari setiap halaman jika mereka menemukan sebuah kutipan atau alusi yang berkaitan dengan teks Perjanjian Bahasa Yunani ini. Referensi kutipan langsung dicetak dengan huruf miring, sedangkan alusi dicetak dengan bentuk huruf biasa. Para editor juga membuat sebuah daftar lengkap berisi semua kutipan dan alusi dalam urutan kanonik Perjanjian Lama yang semuanya dapat ditemukan di margin luar edisi bahasa Yunani ini.

${ }^{63}$ Penyusunan yang sama juga ditemukan di edisi-4 Greek New Testament terbitan United Bible Societies (UBS). Edisi ini mendaftarkan jauh lebih sedikit alusi dibandingkan $\mathrm{NA}^{27}$. Sangat berbeda dengan NA ${ }^{27}$, edisi ini juga mencakup sebuah lampiran berisi kutipan-kutipan yang muncul dalam urutan kanonik Perjanjian Baru. $\mathrm{UBS}^{4}$ juga mendaftarkan berbagai macam paralelisme bersamaan dengan alusi.

${ }^{64} \mathrm{NIV}, \mathrm{NLT}, \mathrm{NEB}, \mathrm{NJB}$, dan sebagainya. Dikatakan sebagai Alkitab terjemahan yang standar, karena di mana dalam marginnya juga terdapat referensi kutipan, alusi, dan paralelisme umum. Referensi di margin terjemahan bahasa Inggris tersebut benar-benar merupakan tambang emas dari kemungkinan referensi terhadap Perjanjian Lama.

${ }^{65}$ Sumber-sumber di bawah ini hanya menyajikan kutipan. Lihat, G. Archer dan G. Chinichigno, Old Testament Quotations in the New Testament: A Complete Survey (Chicago: Moody, 1983); R. G. Bratcher, Old Testament Quotations in the New Testament (London: United Bible Societies, 1984); C. H. Toy, Quotations in the New Testament (New York: Scribner's, 1884). Dapat ditemukan di Google Books; D. M. Turpie, The Old Testament in the New (London: Williams \& Norgate, 1868). Dapat ditemukan di Google Books. Sementara sumber-sumber ini mencakup alusi dan terkadang juga paralelisme. Lihat, G. K. Beale dan D. A. Carson (peny.), Commentary on the New Testament Use of the Old Testament (Grand Rapids: Baker Academic, 2007).

${ }^{66} \mathrm{Di}$ sini konkordansi elektronik mempunyai fungsi-fungsi pencarian khusus untuk menetapkan apakah kombinasi unik dari kata-kata itu muncul di antara berbagai kutipan Perjanjian Lama. Dalam hal ini, beberapa perangkat elektronik yang sangat berguna, seperti; Bibleworks9, GRAMCORD, atau Logos.

${ }^{67}$ C. H. Dodd, According to the Scripture (London: Collins, 1952), 126-33. 
pakar Perjanjian Baru terkait tujuan penggunaan Perjanjian Lama oleh para penulis Perjanjian Baru, termasuk oleh Paulus. ${ }^{68}$

\section{Kesimpulan}

Genre epistolari memiliki prinsip-prinsip hermeneutiknya sendiri. Tidak mungkin mengkaji kitab-kitab dengan menggunakan pendekatan yang sama terhadap genre yang sudah berbeda. Genre tertentu menuntut pendekatan hermeneutik yang cocok dan logis dengan literaturnya. Ini aturan dasar yang mutlak dipegang dalam sistem hermeneutika biblika. Karenanya sebuah kaidah dasar yang khusus mengkaji genre epistolari urgen disuguhkan. Pedoman-pedoman yang dipaparkan dalam artikel ini dapat menolong seorang penafsir memahami makna hakiki yang dimaksudkan Paulus dalam tulisannya.

${ }^{68}$ Lihat misalnya, Zuck mendaftarkan sepuluh tujuan kutipan-kutipan Perjanjian lama oleh para penulis Perjanjian Baru, Zuck, Basic Bible Interpretation, 260-270; sedangkan Beale, mendaftarkan dua belas cara-cara utama Perjanjian Baru menggunakan Perjanjian Lama. Beale, Handbook on the New Testament Use the Old Testament, 69-118. 


\section{Bibliografi}

Aune, David. The New Testament in Its Literary Environment. Philadelphia: Westminster Press, 1987.

Barr, James. The Semantics of Biblical Language. Oxford: Oxford University Press, 1961.

Beale, G. K. Handbook on the New Testament Use the Old Testament-Exegesis and Interpretation. Grand Rapids: Baker Academic, 2012.

Beetham, C. A. Echoes of Scripture in the Letter of Paul to the Colossian, Biblical Interpretation 96. Boston: Brill, 2008.

Bock, Darrell L. "New Testament Word Analysis.” Dalam Introducing New Testament Interpretation. Grand Rapids: Baker Book House, 1989.

Cotterell, P dan M. Turner, Linguistics and Biblical Interpretation (Downers Grove: InterVarsity, 1989.

Deissmann, Adolf. Light from the Ancient East. Diterjemahkan oleh L. R. M. Strachan. London: Hodder \& Stoughton, 1909.

Dodd, C. H. According to the Scripture. London: Collins, 1952.

Fee, Gordon D. New Testament Exegesis. Diterjemah dan disunting oleh Andreas Hauw. Malang: Literatur SAAT, 2011.

Fitzmyer, Joseph A. “Aramaic Epistolograph,” Semeia 22:25-26.

Hays, Richard. Echoes of Scripture in the Letter of Paul. New Haven: Yale University Press, 1989.

Hirsch Jr, E. D. Validity in Interpretation. New Haven: Yale University Press, 1967.

Hughes, F. W. Early Christian Rhetoric and 2 Thessalonians, JSNTSup 30. Sheffield: JSOT, 1989.

Johnson, Alan. "History and Culture in New Testament Interpretation." Dalam Interpreting the Word of God. Disuntingkan oleh Samuel J. Schultz dan Morris A. Inch. Chicago: Moody Press, 1976.

Kaiser, Jr., Walter C. Toward an Exegetical Theology: Biblical Principles for Preaching and Teaching. Grand Rapids: Baker, 1981.

Kennedy, G. A. New Testament Interpretation through Rhetorical Criticism. Chapel Hill: University of North Carolina Press, 1984.

Klein, William W., Craig L. Blomberg, Robert L. Hubbard Jr., Introduction to Biblical Interpretation 2. Diterjemahkan oleh Timotius Lo dan Disunting oleh Chilianha Jusuf Malang. Literatur SAAT, 2013.

Longenecker, Richard N. "On the Form, Function, and Authority of the New Testament Letters," dalam Scripture and Truth, peny. D. A. Carson dan John D. Woodbridge (Grand Rapids: Zondervan, 1983)

Louw, J. P. Semantics of New Testament Greek. Philadelphia: Fortress, 1982.

Nida, E. A dan J. P. Louw, Lexical Semantics of the Greek New Testament. Atlanta: Scholars, 1992.

Osborne, Grant R. The Hermeneutic Spiral: A Comprehensive Introduction to Bible Interpretation. Downer Grove, Ill.: InterVarsity Press, 1991.

Porter, S. E. "Allusion and Echoes." Dalam As It Is Written: Studying Paul's Use of Scripture, peny., S. E. Porter dan C. D. Stanley, SLB Symposium Series 50. Atlanta: Society of Biblical Literature, 2008.

. "Further Comments on the Use of the Old Testament in the New Testament," dalam The Intertextuality of the Epistles: Explorations of Theory and Practice. Disunting oleh T. L. Brodie, D. R. MacDonald, dan S. E. Porter, NTM 16. Sheffield: Sheffield Phoenix, 2007.

Ramm, Bernard. Protestant Biblical Interpretation. Grand Rapids: Baker Book House, 1970.

Roetzel, C. J. The Letter of Paul. Louisville: Westminster John Knox, 1998. 
Silva, Moisés de. “Old Testament in Paul.” Dalam Dictionary of Paul and His Letters. Disunting oleh G. F. Hawthorne, R. P. Martin, dan D. G. Reid. Downers Grove: Ill.: InterVarsity, 1993.

. Biblical Words and Their Meaning: An Introduction to Lexical Semantics. Grand Rapids: Zondervan, 1995.

Stuart, Douglas dan Gordon D. Fee, How to Read the Bible for All Its Worth. Grand Rapids: Zondervan, 1993.

Thiselton, Anthony C. "Semantics and New Testament Interpretation." Dalam New Testament Interpretation. Disunting oleh I. Howard Marshall. Grand Rapids: Eerdmans, 1977.

Virkler, Henry A. \& Karelynne Gerber Ayayo, Hermeneutik: Prinsip-prinsip dan Proses Interpretasi Alkitabiah. Yogyakarta: ANDI, 2015.

White, John L. "Ancient Greek Letter," dalam Greco-Roman Literature and the New Testament: Selected Forms and Genre, peny., D. E. Aune. Atlanta: Scholars Press, 1988.

White, John L. "Ancient Greek Letter," dalam Greco-Roman Literature and the New Testament: Selected Forms and Genre. Disunting oleh D. E. Aune. Atlanta: Scholars Press, 1988.

Zuck, Roy B. Basic Bible Interpretation. Wheaton Ill.: Victor Books, 1991. 